\title{
Les costumes du sud de la Laponie : organisation et désorganisation d'un système symbolique
}

Yves Delaporte

\section{(2) OpenEdition}

1 Journals

Édition électronique

URL : https://journals.openedition.org/tc/798

DOI : $10.4000 /$ tc. 798

ISSN : 1952-420X

Éditeur

Éditions de l'EHESS

Édition imprimée

Date de publication : 1 juin 1989

ISSN : 0248-6016

Référence électronique

Yves Delaporte, "Les costumes du sud de la Laponie : organisation et désorganisation d'un système symbolique », Techniques \& Culture [En ligne], 12 | 1989, mis en ligne le 16 janvier 2006, consulté le 29 septembre 2022. URL : http://journals.openedition.org/tc/798 ; DOI : https://doi.org/10.4000/tc.798

Ce document a été généré automatiquement le 29 septembre 2022.

Tous droits réservés 
Les costumes du sud de la Laponie : organisation et désorganisation d'un système symbolique

Yves Delaporte 